\title{
Acquisition of meaning in bilingual children: Interference, translation and errors
}

\author{
Edita Hornáčková Klapicová* \\ SS Cyril and Methodius University, Slovakia
}

\begin{abstract}
Even though the process of the acquisition of phonology and syntax in bilingual children resembles that of monolinguals, vocabulary acquisition in bilingual children heavily depends on the input in each language. Bialystok (2004, p. 66) holds that "it may be that the acquisition of syntax and phonology is adequately triggered by exposure to the language, but vocabulary needs to be learned". Children appear to have the capacity for acquiring more than the basic volume of vocabulary necessary for one language system. The aim of the present paper is to examine the following aspects: the processes of the acquisition of meaning; the manifestation of interference, transfer and borrowing; the task of finding translation equivalents; errors in vocabulary usage in bilingual children.
\end{abstract}

\section{Key words}

borrowing, interference, meaning, transfer, translation equivalent, vocabulary errors

\section{Introduction}

The semantic component is an important part of the sound-meaning association system in the structure of a language. No "two language-culture communities view reality the same way, and each community's language reflects its world view, what it regards as the significant categories and relations of experience" (Wells Lindfors, 1980, p. 44). ${ }^{1}$ The uniqueness of the human person "resides in the ability to behave symbolically ... while the bilingual or multilingual environment creates ... a unique identity of the child" (Balák, 2005, p. 59).

Benjamin Whorf and others have argued that "one's way of thinking and of viewing the world is determined by the language he learns, for as he learns the language, he is necessarily learning the categories and relations it encodes" (Ibid. p. 45). This view might be extremely deterministic, as humans are capable of learning more than one language and in each language different labels and categorization of items and experiences are used. Therefore, it would be inadequate to state that language controls the way humans think about reality, even though it does propose certain schemes according to which reality is expressed. Wells Lindfors (1980, p. 46) suggests that "the speakers of a particular language view reality in similar ways, in terms of categories and the relationships among them". Therefore, understanding the meaning of words in a language includes knowledge of how the world of a specific community is categorized and labelled (Cf. ibid. p. 46). The words of a language have generally agreed upon or conventionalized meanings.

\footnotetext{
*Address for correspondence: Edita Horň́čková Klapicová, Department of British and American Studies, SS Cyril and Methodius University, Nám. J. Herdu 2, Trnava, Slovakia. E-mail: ehornackova@ progresit.sk

${ }^{1}$ Culture can be understood as a set of [typical] features representing a social group or community (Cf. Smetanova, 2017, p.42).
} 
According to most recent studies (e.g. Patterson and Pearson, 2012; Pearson, 2013; Pearson and Amaral, 2014), the initial lexicon of bilingual children has no equivalents. The child only comprehends that each language operates with a different lexical system and that there are equivalents in the two languages during the second stage of language development. The child must "recognize the prototype of a certain word, take it out of its own pragmatic-semantic field, and identify it with the prototype of another word that belongs to the other language and which possesses its own pragmatic-semantic field" (Taeschner, 1983, p. 41).

As children progress with vocabulary acquisition in two or more languages, they become curious not only about the meaning of words but also about their equivalents in another language. The bilingual child soon learns that two linguistic systems operate via two different sound-meaning relations and the child must acquire both systems in order to achieve the desired communicative function in interactions with speakers of different languages.

Bilingual children can be classified as simultaneous bilinguals or sequential bilinguals, depending on whether they began learning a second language at birth or before the age of three. Simultaneous bilinguals seem to go through two stages of language development. The first stage is an undifferentiated "single language system composed of elements from both languages" (Fierro-Cobas and Chan, 2001, p. 80). The second stage takes place when the child begins to differentiate between the two systems, "using each one as a separate system for distinct purposes" (Ibid. pp.80-81). Sequential bilingual children normally speak the same language (L1) with their parents at home, while a second language (L2) is introduced after the age of three. Simultaneous bilinguals receive the input of two languages as infants and toddlers, "before they are old enough to explicitly or consciously understand that their input comes from two linguistic sources" (Paradis, 2007, p. 17).

The process of acquiring a second language before the age of three is different from the process of first language acquisition. First, "a sequentially bilingual child can draw on knowledge and experience with the first language" (Fierro-Cobas and Chan, 2001, p. 83). Second, the child's temperament and motivation will influence "whether and for how long a child passes through several phases in the sequential language acquisition" (Ibid. p. 83). Third, the amount of exposure compared with first language exposure can have an influence on the development of the second language (Cf. ibid. p. 83).

According to some authors bilingual toddlers have no translation equivalents (proposed, for instance, by Volterra and Taeschner, 1978). This claim is, however, contradicted by subsequent research indicating that "bilingual toddlers' early lexicons consist of $3.9 \%$ to $67 \%$ translation equivalents, depending on children's ages and methods used to determine vocabulary composition" (Paradis, 2007, p. 19). Nevertheless, "there is no consensus about whether the presence of translation equivalents alone constitutes evidence for differentiation at the lexical level" (Ibid. p. 19).

Children acquiring two or more vocabulary systems simultaneously may take advantage of crosslanguage interdependence facilitating the process of their lexical development in the target language. It appears that "learning a translation equivalent for an already lexicalized concept might be faster than learning a new label for a new concept" (Ibid. p. 19). According to research on lexical development in simultaneous bilinguals (including toddlers, preschool and school age children), as a group they tend to "score lower than monolingual age-mates in each language" (Ibid., p. 20). Nevertheless, vocabulary size reflects quantity of input in each language and "bilingual pre-schoolers can score closer to monolinguals in the language in which they receive more input" (Ibid. p. 20). Even though multilingual development in preschool years may result in a smaller vocabulary size in each language than in monolinguals, school age bilinguals may achieve the same size of vocabulary as their monolingual peers, when their "total conceptual vocabulary is taken into account across both languages" (Ibid. p. 20). These data have been collected in the works of Marchman, et al. 2004; Patterson and Pearson, 2004; Pearson, et al. 1993; Pearson, et al. 1997; Pearson, 1998; and Cobo-Lewis, et al. 2002.

\section{Aims of research and methodology}

The aim of the present paper is to provide further insight into the following processes: identifying meaning; the appearance of interference and borrowing; the ability to translate meaning across languages; vocabulary errors in bilingual children as they develop their lexicon. It should contribute to elucidating the question of how a child discovers that there exist two linguistic systems operating via two different sound-meaning relations. 
This longitudinal case study proceeds from the observation of the language development of two children, Stephanie (5 1/2 years old) and Paul (3 1/2 years old), acquiring Slovak, German and English simultaneously during their early childhood. Slovak was the dominant language (mother tongue) of both children. German was acquired in a German-speaking country in natural speaking environments (kindergarten and other). English was acquired from native English speakers (caregivers) also in a natural speaking environment.

The linguistic research material was documented in the form of a diary, and audio and video recordings from the births of both children to their present age in natural settings. The collected empirical data were processed using the methods of qualitative data analysis, description, evaluation and interpretation. Examples 1 through 40 provided in this paper are samples from authentic recordings of Stephanie's and Paul's speech and their interactions with other speakers.

The outcomes of the present case study support the theory that a child's early lexicon may already consist of translation equivalents.

\section{Identifying meaning in bilingual children}

Bilingual children acquire specific linguistic forms in association with the meaning they convey. They adopt the sign (spoken symbol) conventionally used to refer to a certain object, thing or reality in the real or imaginary world. In each language, different concepts are perceived in different ways; therefore, the semantic components of words and expressions vary across languages. This discrepancy between linguistic forms and their meanings is due to the heterogeneity between cultures that manifest their way of understanding the world around them dissimilarly through language. Linguistic performance documented in the present case study advocates for the presence of translation equivalents as well as for differentiation at the lexical level. It appears to be true, however, that bilingual children's timetable for the development of vocabulary "may be somewhat altered by the dual language experience" (Paradis, 2007, p. 19).

\subsection{Defining meaning of words}

Bilingual children show an extraordinary facility for defining the meaning of words both in the source language and in the target languages. In the following examples, Stephanie and Paul demonstrate their ability to define words as well as their curiosity about the meaning of words and phrases in different languages.

Example 1: Paul playing with his monster truck toy with Grace, an American university student. Grace: "What's a monster truck, Palko?"

Paul: "Jump in mud and splash water."

Grace: "And does it get all muddy?"

Paul: "My...your turn!"

Grace: "What if we make a high jump?"

Paul: "A diving board. Help me, please. Three, two, jump!"

In Example 1, Paul used the target language to explain the meaning of 'monster truck' to the Englishspeaking caregiver. Even though syntactically his definition was not correct due to the missing subject, he was capable of quite clearly communicating the meaning of the expression in question.

\section{Example 2}

Stephanie: "Maminka, čo je to nickname?" (Mom, what is a 'nickname'?)

Mother: "It's another name for someone. Like 'Kuka' is a nickname for Števko."

Stephanie: “Aj ja mám nickname?" (Do I also have a nickname?)

Mother: "I don't know."

Stephanie: "Ja viem! Fifinka!" (I know! Fifinka!)

Stephanie's mother often intentionally answered Stephanie's questions regarding the meaning of words in different languages in the target language (or the source language of the word in question). 
Thus, the meaning of the word in Example 2 was explained against a context and co-text in the target language.

\section{Example 3}

Stephanie: "Mami, čo je to first spring day?" (Mom, what's 'first spring day'?)

Mother: "To je pryý jarný deň." (It is first spring day.) (Mother used Slovak to explain the English expression.)

\section{Example 4}

Stephanie: "Mami, čo je to in the morning?" (Mom, what's 'in the morning'?)

Mother: "No, ved' ráno!" (Well, [in the] morning!)

\section{Example 5: Stephanie wondering about the meaning of her mother's friend's name.}

Stephanie: "Mami, prečo sa ona volá ,Rosa' - 'ružová'?" (Mom, why is her name 'Rosa' - 'pink'?) ('Rosa' is a German female name.)

Stephanie often pondered about the meaning of words and expressions in different languages, as shown in Examples 3, 4 and 5. She also often asked questions about how some ideas were expressed in the languages she was not acquiring, for instance, in Italian. She enjoyed listening to other languages and wanted her mother to read her stories in other languages. Even though she did not understand the language, she tried to guess the meaning of words from the pictures she saw in children's books and from identifying cognates. For example, Stephanie was capable of recognizing the meaning of 'mamma' and 'parco' in the Italian sentence 'Se non piove, la mamma mi porta al parc'. In the same manner, she was able to identify the meaning of the Italian words 'papà' (daddy), 'pigiamino' (pyjamas), 'disegnare' (draw), 'pirati' (pirates), 'gnam!' (yum!), 'zuppa' (soup), 'sapone' (soap).

\subsection{Grouping words into semantic domains}

Humans tend to assign everything that is perceived in the world around them to categories. Most of this categorization activity happens automatically and unconsciously. This process may involve using labels for concepts in different languages in the bilingual child, depending on their association of the label with the concept.

Example 6: Paul and Stephanie playing the game "Guess, what's on my mind!" whereby one of the participants creates an image of an object in his or her mind and the rest of the participants in the game try to reveal what object it is by naming it.

Stephanie: "Hádaj, na čo myslím!" (Guess, what’s on my mind!"

Paul: "Bycikel? (A bike?)

Stephanie: "Nie." (No.)

Paul: "Auto?" (A car?)

Stephanie: "Nie." (No.)

Paul: "Motorka?" (A motorcycle?)

Stephanie: "Nie." (No.)

Paul: "Traktor?" (A tractor?)

Stephanie: "Nie." (No.)

Paul: "Monster truck?"

Stephanie: "Nie." (No.)

Paul: "Snow mobile?"

Stephanie: "Nie." (No.)

All of the words Paul used in Example 6 were labels for different types of vehicles, which all contained the semantic features 'means of transport', 'wheeled' and 'moving on the ground'. Moreover, he used either Slovak and English labels to name an object whose concept was, in his mind, associated with a specific meaning-sound correspondence. 


\subsection{Lexical gap}

Lexical acquisition in sequential bilinguals differs from lexical acquisition in simultaneous bilinguals to a certain degree. L2 children use non-specific nominals more frequently and they tend to use sound symbolism or code-switching to express meaning for a word they do not know in the target language. Even though recent studies demonstrate that L2 children are more likely to lag behind monolinguals on tests of productive vocabulary, Patterson and Pearson (2004) suggested that "older sequential bilingual children may take advantage of cognates to enhance L2 language acquisition, for literacy in particular (Paradis, 2007, p. 27).

Example 7: Stephanie talking to Emilie about what happened in kindergarten during the day. Stephanie: "Elias macht die Palko aua im Kindergaten." (Elias 'did/made' Paul 'ouchie' in kindergarten.)

Stephanie used the non-specific nominals macht and aua to fill the lexical gap in Example 7.

\section{Interference, transfer and borrowing in bilingual children}

\subsection{Interference}

Children acquiring their L3 often search for recourses in the language that is typologically closer to the L3. This means that their dominant language is not necessarily the source language for lexical interference.

Based on research with bilingual children Bialystok (2004) has come to the conclusion that "children are not credited with knowing the name for something in the two languages but for the breadth of concepts that are labelled by their cumulative lexical resources" (Bialystok, 2004, p. 64). If the child's conceptual range is high, he will be likely to use the two languages in different contexts and for specific functions. Therefore, the child will not simply use the second language to mirror the dominant one, but rather use a specific label to designate an individual concept.

\subsection{Transfer}

Transfer of linguistic features between languages is a cross-linguistic influence in the speech repertoire of a bilingual or multilingual individual.

Example 8: Stephanie talking to her aunt about her grandmother's broken back. Stephanie: "Babička má pokazený chrbát." (Grandma has a broken back.)

The adjective 'pokazený' in Example 8 is clearly a semantic transfer from the English adjective 'broken'. While 'broken' in English collocates with 'bone', 'arm', 'leg' and 'back' with the meaning 'to fracture', there is an asymmetry in the semantic components between the English verb 'break' and the adjective 'broken' and the Slovak verb 'pokazit' and the adjective 'pokazeny'. 'Broken' and 'pokazený'share the semantic component 'to damage a machine so that it does not work properly', however, the component 'to damage a bone in your body by making it crack or split' is only contained in the English verb 'break' and adjective 'broken' as showing the result of the action, but not in the Slovak verb 'pokazit'. The meaning of 'damage a bone in your body by making it crack or split' would be expressed by the Slovak verb 'zlomit" and the result of this action would be expressed by the adjective 'zlomený'.

Example 9: Stephanie and Paul arguing about who is 'bigger', their mom or their mother's brother Stefan. ('Kuka' is a nickname for 'Stefan'.)

Stephanie: "Maminka je Kukova vel'ká sestra." (Mom is Kuka’s big sister.)

Paul: "Neni, Kuka je vel'ký!" (She isn't, Kuka is big!)

Stephanie: "Ale maminka sa narodila prvá. Tak je vel'ká sestra." (But mom was born first. So, she’s big sister.)

Paul: “Ale neni. Maminka neni vel'ká sestra. Kuka je vel'ký od maminky.” (But she isn’t. Mom's not big sister. Kuka is bigger than mom.)

Stephanie: "Nie, maminka je vel'ká od Kuka." (No, mom is bigger than Kuka.) 
The dispute about who is whose 'big sister' or 'big brother' in Example 9 is quite ambiguous. The expression 'big sister' in English means 'older sister'. However, this concept is not expressed in the same fashion in Slovak. Stephanie apparently transferred the meaning of the English expression (which she was familiar with) into Slovak by simply translating its components and creating a new lexeme (in this case a calque) in the target language: "big sister" $\rightarrow$ "vel'ká sestra". On the other hand, her brother Paul did not seem to understand the meaning of the calque and associated the Slovak expression 'vel'ká sestra' with the literal meaning of its components. In fact, it was Paul who made an accurate judgement about the meaning of the Slovak expression. Notwithstanding, the argument of the conversation above triggered quite an amusing discussion between the two speakers.

\section{Example 10: Stephanie and Paul talking about their age.}

Stephanie: "Ja som štyri rokov." (I'm four years [old].)

Paul: "Aj ja som štyri... Aj ja budem mat' štyri rokov. Ja mám tri roky." (I too am four... I too will be four years old. I'm three years old.)

Stephanie: "Všetci moji kamaráti sú štyri, tri, dva a jeden." (All of my friends are four, three, two and one.)

In Example 10, Stephanie transferred the construction 'to be x years old' into Slovak using the same components as they are used in English. In fact, it is not quite clear whether the interference is caused by English or German, as the expression in German consists of the same components as in English ' $x$ Jahre alt sein' (to be x years old). In Slovak, however, talking about age includes the verb 'have' instead of 'be': 'mat' $\mathrm{x}$ rokov' with the corresponding singular or plural morpheme attached to the stem 'rok' (year), e.g. 'Mám štyri roky.' (I'm four years old.) Paul, however, even though mirroring Stephanie's transferred construction in his first sentence: "Aj ja som štyri..." (I too am four...), applied the appropriate Slovak construction in the subsequent sentences: "Aj ja budem mat' štyri rokov. Ja mám tri roky." (I too will be four years old. I'm three years old.)

\subsection{Borrowing}

Bilingual children often borrow words from the source language (producing code-mixing) if they cannot recall or do not know the corresponding equivalent in the target language, or if they do not find the translation equivalent sufficiently accurate in reference to a specific concept.

Example 11: Stephanie, Paul and Delaney, an American university student, are singing a song about a monkey playing at the bay. Children fill in the names of different animals and the activities the animals do.

Stephanie: “...elephant tanzen...” (...elephant dances...) (borrowing from German)

Mother: "Elephant dances?"

Stephanie: "Yes."

\section{Example 12: Stephanie playing with Delaney.}

Stephanie: "Will you ice-cream?" (Do you want ice-cream?)

Stephanie borrowed the verb form "will" from German, meaning "want", with the German pronunciation of "will" $\rightarrow$ [vil].

Nevertheless, the choice of borrowing is often closely associated with the context in which the borrowing is used. The reasons for borrowing in Examples 11 and 12 might include a lexical gap in the target language or the immediate state of mind. When the child frequently alternates languages, it naturally occurs that they resort to another language if the word in the target language does not immediately come to mind.

\section{Example 13}

Stephanie (to her mother): "Maminka, ty máš krásny necklace!" (Mom, you've got a beautiful necklace!) 


\section{Example 14}

Stephanie (to her brother): "Toto musíš weg räumen!" (You’ve got to put this away.)

Example 15: Paul putting his slippers away when going to bed.

Paul: “Good night! Papučky, good night!” (Good night! Good night, slippers!)

Example 16: Stephanie addressing her friend Emilie (6) in German and her mother in Slovak. Stephanie (to Emilie): "Ich kann so machen. Ich like..." (I can do it. I like...) (switching to English) Stephanie (to her mother): "Look, mami!" (Look, mom!) (switching to English again)

Sometimes any of the languages can serve as a source of lexical interference, as demonstrated in Examples 13-16.

\section{Example 17: Paul counting.}

Paul: "Eins, zwei, drei, four, six, seven, sedemnást', osemnást'."

Paul gradually switched from German to English and then to Slovak when counting in Example 17.

Stephanie often switched codes when talking to her mother. There are instances of multiple codeswitches from German to Slovak to English in her speech. In her case, code-switching is often conditioned by a relevant semantic component within a specific context, for instance, donut (English) vs. šiška (Slovak): no direct equivalent in Slovak; cup-cake (English): no direct equivalent in Slovak; die Elsa Farbe (German) - Elsa colour (English) - elsovská farba (Slovak): naming a specific colour (blue and turquoise) that was used about the main character Elsa in the animated film Frozen; Erdbeere icecream (German + English): referring to a flavour of icecream; or Elsa icecream (English): referrring to the colour of icecream, bubble gum (English) and chewing gum (English) as two different equivalents of žuvačka (Slovak) conveying different meanings in each of the English equivalents.

Example 18: Stephanie's and Paul's mother reading 'Aschenputtel' to the children in German. Having finished reading the bedtime story, the mother asked Stephanie several questions in Slovak to check whether she had understood the German text. One of the questions was about the main protagonist's name.

Mother: "Kto je Aschenputtel?" (Who is 'Aschenputtel'?)

Stephanie: "Cinderella." (Answered in English.)

Even though in Example 18 the mother asked questions about the story in Slovak, Stephanie provided the English name for 'Aschenputtel', which is 'Cinderella'. Stephanie had previosuly heard the story and seen a film about Cinderella in both Slovak and English; however, she provided the English equivalent for the German name of the main protagonist, even though she knew the Slovak equivalent 'Popoluška'.

Example 19: Paul talking about a game played in their English class.

Paul: “Ked' sa ja pomýlim, musím 'Bank setzen'." (When I make a mistake, I have to go to sit on the bank.)

Paul introduced the first part of his sentence in Example 19 in Slovak, as the conversation was taking place between his mother, sister and himself: "Ked' sa ja pomýlim, musím". However, he finished the sentence in German: 'Bank setzen'. The reason for borrowing the expression from German is likely to be the fact that Paul spends quite some time in the gym with his peers in kindergarten, where the English class normally takes place. While performing various activities in the gym under the guidance of his teachers, Paul had acquired the collocation in German "[sich auf der] Bank setzen" in association with the corresponding activity. 
Example 20: Stephanie and Paul observing the shadows on the wall made by the movements of their hands against the light of a lamp.

Stephanie: "Toto je môj 'shadow', tu je 'shadow'." (This is my shadow, here is a shadow.)

Stephanie used the English equivalent 'shadow' in her Slovak sentence in Example 20, probably due to a lack of a Slovak equivalent. However, wishing to accurately name the concept, she chose to borrow the English label for it.

Example 21: Stephanie talking to her mother about a St. Valentine's Kasperlbühne (Punch and Judy show) coming to her kindergarten one day.

Stephanie: “Ale my potom nebudeme na 'Kasperl', ked' pôjdeme do Hrádku." (But then we won’t be there for Punch and Judy, if we are going to Hradok.)

In example 21, Stephanie naturally used the German label 'Kasperl' to refer to this unique concept associated with a famous and traditional puppet character from Austria, German-speaking Switzerland, and Germany. The German 'Kasperl' could be translated into Slovak as 'šašo' (clown), which would then reduce the distinctive meaning of the original German proper noun to the general meaning of the common noun 'clown'.

Example 22: Stephanie preparing to go on a hike from kindergarten. Regina is the principal of the school.

Stephanie (to her mother): "Ale ja nemôžem takúto glassovú flašu, Regina povedala, aby sa nerozbila." (But I can't [bring] such a glass bottle, Regina said, so it wouldn't break.)

Mother: "Das ist Glass, aber das ist nich Glass. (That is glass but that is not glass.) (Replying in German while pointing at different bottles made of different material, assuring that Stephanie was not going to bring a glass bottle on the hike.)

The process of borrowing can often be affected by cross-linguistic interference, for instance, by applying the rules of declension from the source language and adding other derivational morphemes (such as in the creation of a feminine singular adjective), as in Example 22. Stephanie adapted the English root morpheme 'glass-' to the morphological rules of Slovak by adding the suffix '-ovú'.

Example 23: Stephanie playing with her mother in snow. The sun was shining.

Mother: "Števinka, pozri, ako sa ten sneh krásne trblieta." (Stevinka, look, the snow glitters so beautifully.)

Stephanie (pointing at the snow): "Ako sa volá?" (What's it called?)

Mother: "Že sa trblieta?" (That it glitters?)

Stephanie: "Sparkles!" (In English.)

Mother: "Trblietky."

Stephanie: "Trblietky?" [Having difficulty pronouncing the Slovak word]

Stephanie continues playing. After a while:

Stephanie: "Mne sa páčia takéto 'sparkles"”. (I like such sparkles.)

Example 23 suggests that Stephanie probably acquired the English word 'sparkles' from English cartoons. As she had no previous practice with the Slovak equivalent 'trblietky', she probably found it easier to use the English word again in her conversation with her mother.

Example 24: Stephanie watching Blippi, a children's educational video and commenting on the geography topic presented in the video.

Stephanie: "Mami, tam je iba teplo. Lebo 'in Africa' býva iba teplo. 'In Africa' je len teplo." (Mom, it's always warm there. Because it's always warm in Africa. It's warm only in Africa.)

In Example 24 Stephanie borrowed the collocation 'in Africa' from Blippi, as it designated a 'remote country' in her understanding. She was not quite familiar with the continents yet; therefore, she was unable to find the corresponding equivalent in her mother tongue. 


\section{Finding translation equivalents in bilingual children}

Stephanie and Paul understood that in different languages different institutionalized expressions were used, such as greetings and other polite expressions of thanks or apology. When on vacation abroad, they quickly acquired the meaning and learned how to use expressions such as the Italian 'Ciao', 'Grazie', 'Prego', 'Scusi', 'Buon giorno', 'Brava', 'Bene' or the Spanish 'Hola', 'Adiós', 'Gracias', 'Hasta luego', 'Por favor', 'Bueno'.

\section{Example 25}

Stephanie: "Maminka, žlté je pink?" (Mom, is yellow pink?)

Mother: "Nie, yellow." (No, yellow.)

Stephanie: "Aha, slniečko! Ružové má dievčatko [čiapočku], pink." (Oh, the sun! The girl has a pink [hat].)

\section{Example 26}

Stephanie: "Maminka, ako sa povie po nemecky ball?" (Mom, what's ball in German?)

Mother: "Ball. Der Ball." (Ball. The ball.)

Stephanie: "Jáj, der Ball!"

\section{Example 27}

Stephanie: "Mami, ako sa povie po nemecky, že je to smiešne?" (Mom, how do you say it's funny in German?)

Mother: "Lustig?" (Funny?)

Stephanie: "Áno!" (Yes!)

...

Stephanie: "Maminka, ako sa povie po nemecky 'jablko' ?" (Mom, how do you say 'apple' in German?) Mother: "Apfel." (Apple.)

Stephanie: "A 'banány'?" (And 'bananas'?)

Mother: "Bananen." (Bananas.)

Stephanie: "A 'mandarinka'?" (And 'tangerine'?)

Mother: "Mandarine." (Tangerine.)

Example 28: Paul taking a bath.

Delaney: (to Paul) "How do you say cold in Slovak?"

Paul: "Studené!" (Cold.)

Examples 25-29 demonstrate Stephanie's and Paul's search for equivalents of words or labels for concepts across languages.

\section{Example 29}

Stephanie: "Mami, ako sa povie praženička po anglicky?" (Mom, what's scrambled eggs in English?) Mother: Scrambled eggs.

Stephanie: "A párček? (And a hot dog?)

Mother: Hot dog.

Stephanie: (Unsatisfied with the answer). "Ale uvarit’ párček!" (But to cook a hot dog!)

Mother: Hot dog. Ty myslíš, že hot dog je párček v rožteku? (Hot dog. Do you think hot dog is sausage in a bread roll?)

Stephanie: “Áno.” (Yes.)

Example 29 shows that in Stephanie's understanding the English expression hot dog is a different concept from the Slovak párok. The Slovak párok refers to a piece of sausage on a plate accompanied by a piece of bread and ketchup. While hot dog is a piece of sausage inside a bread roll. Stephanie has narrowed down the meaning of hot dog from 'a type of sausage sandwich' to 'a type of sausage' on her own and independently of the latter American usage. 


\section{Example 30}

Stephanie: "Maminka, ako sa povie po nemecky 'na pery'?" (Mom, how do you say 'lip stick' in German?)

Mother: "Lip stick."

Stephanie: "Ale to neni po nemecky!" (But it is not in German!)

Mother: "Neviem, máš pravdu, to je po anglicky." (I don’t know, you're right, it's in English.)

Stephanie: "A ako sa povie palica?" (And how do you say stick?)

Mother: "Stick." (Stick.)

Stephanie: "Ale to neni po nemecky!" (frustrated) (But it's not in German!)

In Example 30, Stephanie's mother did not immediately recall the equivalents for 'lipstick' ('der Lippenstift') and 'stick' ('der Stock') in German. Stephanie recognized the English translations her mother provided and displayed frustration over not obtaining the desired answers.

\section{Example 31: One morning Stephanie asking her mother.}

Stephanie: "Maminka, ako sa povie 'dobrú chut" po anglicky?" (Mom, how do you say 'bon appétit' in English?)

Mother: "Enjoy your meal."

Stephanie: "Ale nie tak! Inak." (But not so! Some other way!)

Stephanie was not satisfied with the equivalent her mother provided for the Slovak expression in Example 31. She thought there should be a more suitable one.

\section{Example 32: At the swimming pool. Paul accidentally bumped into Stephanie.}

Delaney: (to Paul) "Can you say I'm sorry to Stevka?"

Paul: "I'm sorry."

Delaney: (not having heard clearly what Paul said) "But can you apologize to her? Apologize means 'I'm sorry“."

Paul: (explaining to Delaney) "Apologize Slovak 'prepáć.”

Example 33: Delaney practicing the construction , not anymore' with Stephanie and Paul, while using different examples, such as ,I'm not your friend anymore'.

Paul: (to his mother) "Delaney neni friend. Neni moj kamarát." (Delaney isn't friend. She isn't my friend.)

Mother: "Delaney said she wasn't your friend anymore? But she IS your friend!"

\section{Example 34: Paul talking to his mother.}

Paul: "Maminka, ja t’a l'úbim again!" (Mom, I love you again.)

Mother: "Čo je to again?"

Paul: "Ešte raz." (Again/one more time.)

Upon mixing codes, Paul often tried to also find the appropriate equivalent in the target language, as in Examples $32-34$ above.

Example 35: Paul talking to Kat, an American university student.

Paul (to Kat): "Theresa, ja t’a lúbim." (Theresa, I love you.)

Paul's mother (to Paul): "Her name is not Theresa, her name is Kat."

Paul (to Kat): "Ja t’a l'úbim, Kat." (I love you, Kat.)

Paul's mother (to Paul): "Musíš jej to povedat' po anglicky." (You've got to tell her in English.)

Paul (to Kat): "How are you today?"

Example 35 creates an amusing interaction between Paul, his mother and Kat. While making a great effort to express his feelings towards Kat, Paul ultimately fails to get the message across by choosing the wrong expression in English. 


\section{Example 36: Having returned home from kindergarten.}

Stephanie: "Mami, Regina hovorila, že sa chce s tebou rozprávat'." (Mom, Regina said she wanted to talk to you.)

Mother: "Naozaj? A ako to povedala?" (Really? And how did she say it?)

Stephanie: "Ich will deine Mama sagen was." (I want to say something to your mom.)

Mother: "Naozaj?" (Really?)

Stephanie: "Ale nie." [laughing] (But no.)

Stephanie's mother was not sure whether Stephanie was telling the truth. Therefore, she asked Stephanie to say what Regina (the principal) supposedly said in German. Even though Stephanie was able to translate the whole sentence into German, she confessed it was a lie. Example 36 demonstrates that bilingual children are capable of translating complete thoughts from one language into another.

\section{Errors in vocabulary usage in bilingual children: overextension, underextension, overlap and mismatch}

Most linguists agree that the growth of a child's lexicon is related to the child's cognitive development. In early childhood, children make "consistent, classifiable errors in their efforts to use their fledgling vocabularies... [which] takes on new dimensions when a second language is added". Typical lexical errors made by children are frequently the result of overextension and underextension (Anglin, 1977;

\subsection{Overextension}

The most frequent lexical mistake children make is overextension. It means applying words "beyond their usual meaning" (Bialystok, 2004, p.25). This process indicates that "children's lexicons contain incomplete entries for the semantic features" (ibid., p. 25). The concepts to which words are overextended typically share "some perceptual or functional feature with the actual meaning of the word", and children attempt "to label an unknown concept with a known word on the basis of analogy" (ibid., p. 25). Overextension is "more likely evidence of strategic use of language than it is of children's semantic or conceptual incompetence" (ibid. 25).

\section{Example 37: 'Palko'}

When Stephanie was two years old, her baby brother Paul (Palko) was born. For the following few months, she overextended the proper name Paul (Palko) to every other baby that she saw. She even referred to herself with the name 'Palko' when she saw a baby picture of herself. In her understanding, 'Palko' was a common name for 'baby'.

\section{Example 38: 'masielko'}

Around the same age, Stephanie used the label 'masielko' (butter) for everything that was spread over a slice of bread (jam, honey, soft cheese, etc.).

\section{Example 39: 'Christmas tree'}

At Christmas time, Stephanie referred to every Christmas decoration, especially Christmas lights with the label 'Christmas tree'. Even when someone was wearing a red and white outfit, she called that person 'Christmas tree'.

\subsection{Underextension}

Underextension occurs when a child fails to extend a particular word to other objects in the same category. It means the child uses the word in a very restricted way. 


\section{Example 40: 'Casa'}

During the first three years of her life, Stephanie referred to her house exclusively with the Spanish common noun for 'house' $\rightarrow$ 'casa'. She had often heard her mother tell her "Vamos a casa" (We're going home). Thence comes the underextension of the common noun.

\section{Conclusions}

(1) As children acquire their vocabulary in L1 and L2 or also L3 in context in a natural setting, they become sensitive to the nuances and shades of meaning of the words and may sometimes find it difficult to find the appropriate equivalent, provided that there is asymmetry in meaning between synonyms and translation equivalents.

(2) Bilingual children often use non-specific nouns and verbs and onomatopoeic words with higher frequency than their monolingual peers. This is due to their lack of specific vocabulary in the target language.

(3) Bilingual children can be very curious about the meaning of words across languages. They possess an extraordinary facility for creating novel words and building compounds out of the elements they already know. They use language not only to achieve a specific communicative function but also to entertain themselves by playing with words and sounds.

(4) Bilingual children are capable of translating not only words and simple expressions but also complete thoughts from one language into another.

(5) The development of vocabulary in early childhood is accompanied by consistent, classifiable lexicalsemantic errors, which are related to the child's cognitive development and the number of languages they are acquiring.

(6) The findings from the present research display evidence for the growth of translation equivalents in the early stages of bilingual development of speech.

\section{Acknowledgement}

The author gratefully acknowledges the contribution of the Scientific Grant Agency of the Slovak Republic under the grant 1/0454/18.

\section{References}

Anglin, J.M., 1977. Word, object, and conceptual development. New York: Norton.

Balák, R., 2005. Ludská prirodzenost' ako fundament dôstojnosti osoby. Človek - príroda-kultúra . Brno: Masarykova univerzita, pp. 55-67.

Bialystok, E., 2004. Bilingualism in development: Language, literacy, and cognition. Cambridge: Cambridge University Press.

Clark, E.V., 1973. Nonlinguistic strategies and the acquisition of word meanings. Cognition, 2, pp. 161-182.

Cobo-Lewis, A. et al., 2002. Effects of bilingualism and bilingual education on oral and writtenEnglish skills: A multifactor study of standardized test outcomes. In: D. Kimbrough Oller and R. Eilers, eds. Language and literacy in bilingual children. Clevendon: Multilingual Matters, pp. 64-97.

Dromi, E., 1987. Early lexical development. Cambridge: Cambridge University Press.

Fierro-Cobas, V. and Chan, E., 2001. Language development in bilingual children: A primer for pediatricians. Contemporary paediatrics, vol. 18, no. 7. Memphis, TN: Stuttering Foundation of America, pp. 79-98.

Marchman, V.A. et al., 2004. The language specific nature of grammatical development: Evidence from bilingual language learners. Developmental Science, vol. 7, issue 2, pp. 212-224.

Paradis, J., 2007. Early bilingual and multilingual acquisition. Handbook of multilingualism and multilingual communication, vol. 5, Mouton de Gruyter.

Patterson, J. and Pearson, B. Z., 2004. Bilingual lexical development: influences, contexts, and processes. In: Brian Goldstein, ed. Bilingual language development and disorders in SpanishEnglish speakers, Baltimore: Brookes, pp.77-104.

Patterson, J. and Pearson, B. Z., 2012. Bilingual lexical development: Assessment and intervention. In: G. Goldstein, ed. Bilingual language development and disorders in Spanish-English speakers, 2nd edition. Baltimore, MD: Paul Brookes, pp. 113-129. 
Pearson, B. et al., 1993. Lexical development in bilingual infants and toddlers: Comparison to monolingual norms. Language Learning, vol. 43, pp. 93-120.

Pearson, B. et al., 1997. The relation of input factors to lexical learning by bilingual infants (ages 10 to 30 months). Applied Psycholinguistics, vol. 18, pp. 41-58.

Pearson, B., 1998. Assessing lexical development in bilingual babies and toddlers. International Journal of Bilingualism, vol. 2, pp. 347-372.

Pearson, B. Z. and Amaral, L., 2014. Interactions between input factors in bilingual language acquisition: Considerations for minority language maintenance. In: T. Gruter and J. Paradis, eds. Input and experience in bilingual development. Trends in Language Acquisition Research (TiLAR), vol. 13. Amsterdam: John Benjamins, pp. 99-117.

Pearson, B. Z., 2013. Distinguishing the bilingual as a late talker from the later talker who is bilingual. In: L. Rescorla and P. Dale, eds., Late talkers: Language development, interventions, and outcomes. Baltimore MD: Paul Brookes, pp. 67-87.

Smetanová, E., 2017. Možnosti využitia niektorých kultúrnych a sociologických aspektov pri vyučovaní cudzieho jazyka. In: Lančarič, D., ed. Jazykovedné, literárnovedné a didaktické kolokvium XLIII. Linguistic, literary and didactic colloquium XLIII. Bratislava: ZF Lingua, pp. 4249.

Taeschner, T., 1983. The sun is feminine: A study on language acquisition in bilingual children. Berlin: Springer.

Tomasello, M., 1992. First verbs: A case study of early grammatical development. Cambridge: Cambridge University Press.

Volterra, V. and Taeschner, T., 1978. The acquisition and development of language by bilingual children. Journal of Child Language, vol. 5, pp. 311-326.

Wells Lindfors, J., 1980. Children's language and learning. Englewood Cliffs, N.J.: Prentice-Hall, Inc. 